\title{
Miranda
}

Revue pluridisciplinaire du monde anglophone /

Multidisciplinary peer-reviewed journal on the English-

speaking world

\author{
16 | 2018 \\ L'expérimental dans la littérature et les arts \\ contemporains
}

\section{Émeline Jouve, Aurélie Guillain and Laurence Talairach-Vielmas (eds), Unspeakable Acts : Murder by Women/L'acte inqualifiable ou le meurtre au féminin}

\section{Elizabeth Mullen}

\section{OpenEdition}

1 Journals

\section{Electronic version}

URL: http://journals.openedition.org/miranda/12063

DOI: 10.4000/miranda.12063

ISSN: 2108-6559

\section{Publisher}

Université Toulouse - Jean Jaurès

\section{Electronic reference}

Elizabeth Mullen, "Émeline Jouve, Aurélie Guillain and Laurence Talairach-Vielmas (eds), Unspeakable Acts : Murder by Women/L'acte inqualifiable ou le meurtre au féminin ", Miranda [Online], 16 | 2018, Online since 05 June 2018, connection on 16 February 2021. URL: http://journals.openedition.org/miranda/ 12063 ; DOI: https://doi.org/10.4000/miranda.12063

\section{This text was automatically generated on 16 February 2021}

\section{(c) (i) () $\Theta$}

Miranda is licensed under a Creative Commons Attribution-NonCommercial-NoDerivatives 4.0 International License. 


\title{
Émeline Jouve, Aurélie Guillain and Laurence Talairach-Vielmas (eds), Unspeakable Acts: Murder by Women/ L'acte inqualifiable ou le meurtre au féminin
}

\author{
Elizabeth Mullen
}

\section{REFERENCES}

Émeline Jouve, Aurélie Guillain and Laurence Talairach-Vielmas (eds), Unspeakable Acts : Murder by Women/L'acte inqualifiable ou le meurtre au féminin (Berne : Peter Lang, 2016), 276 p, ISBN 978-2875743640

1 Originally presented as part of an international conference in Toulouse on February 9 and 10, 2015, the 14 essays of this fascinating volume delve into historical and fictional murders by women and what we can learn from the ways in which these killings are interpreted. After a thorough introduction, the collection (in English and in French) is organized chronologically into two main sections: the first deals with literary renditions of famous murder cases; the second examines the ways (mostly) contemporary writers reflect on the relationship between literature and violencespecifically, violent, "unspeakable" acts committed by women.

2 Jouve, Guillain and Talairach-Vielmas introduce the volume through the example of two well-known $19^{\text {th }}$-century murder cases: Constance Kent and Madeline Smith. In spite of convincing evidence against them, each was given the benefit of the doubt by a society incapable of imagining that young ladies from such good families could also be murderous monsters. The editors point out how literary interpretations of women who kill continually run up against powerful stereotypes-from the ogress and the femme 
fatale to the more problematic "angel of the house"-no matter what the actual figures of any given period may be in terms of reported violence by women. They also underline the importance of going beyond such figures as Medea, Circe, or Lucrecia Borgia to take a fresh look at the historical and literary contexts surrounding representations of women who kill.

Before outlining the contributions of each essay, the editors provide a brief summary of the critical literature surrounding the question of violence by women, starting with Mary Hartman's 1985 work on murderesses in $19^{\text {th }}$ century France and England. They point out that the mass of critical work on violence by women pales in comparison to the number of studies dedicated to patriarchal violence and to masculine domination (in Bordieusian terms), a point underlined in Céline Dauphin's and Arlette Farge's 1997 work. Dauphin and Farge understand the relative scarcity of critical analysis of violence by women as evidence of a political and ethical reticence to bring it up in the context of such overwhelming violence against women.

4 Nonetheless, the editors show, the 1990s were marked by an upsurge in critical analysis of women who kill. They posit several possible explanations for this, ranging from the interpretation of violence by women as a kind of self-defense in the face of systemic violence against them to the study of violence by women as a consequence of analytical developments in gender studies, crime studies, and prison studies, as well as a renewed taste for crime fiction (especially on television) in general and in scholarly circles since 1990.

5 Comparing different approaches in France and in English-speaking countries, the editors point out a marked preference in France for historical or historiographical studies of deviance and imprisonment (both penitentiary and medical), citing the works of Claudie Lesselier, Yannick Ripa and Cesare Lombrosco, among many others. They note that works by sociologists, legal experts and psychologists provide social, economic and institutional context through which to understand violent crimes committed by women. In France, analysis there is of literary representations of violence by women tends to focus on mythological figures and to take a more feminine than feminist approach. Texts from English-speaking countries, on the other hand, have been more overtly feminist and political in their approach, as well as focusing specifically on Law Studies, as evidenced in the dozen or so works mentioned. Starting with Ann Jones's 1980 study, Women Who Kill, vast numbers of scholars in Englishspeaking countries have focused on representations of violence by women in literature and, in the $21^{\text {st }}$ century, on screen.

6 Finally, before outlining individual contributions, the editors give voice to their own views as to how the current volume builds on and adds to current critical discourse. Their ambition is to explore how historical analysis and discursive practices interact to represent female killers as deviant within a given context and across a broad spectrum of violence, from the $16^{\text {th }}$ to the $21^{\text {st }}$ century in Europe, North America and Africa. Moreover, they look to show how interpretations and representations of acts of violence differ from cultural and temporal context to cultural and temporal context. For the most part, they succeed admirably.

7 The section dealing with literary renditions of historical murders opens with Frédérique Fouassier-Tate's exploration of the representation of husband killers in two late $16^{\text {th }}$-century British plays, Arden of Faversham (1592) and A Warning for Fair Women (1599). She notes that these murders must be read as acts of transgression against both 
family and state (shown to be cut of the same patriarchal cloth) and, through this very transgression, as acts of feminine agency. She further analyses how the apparently moralistic tone of both plays belies the undercurrent of instability and malaise conveyed in the plays' ambiguous portrayal of the murdering wives, inviting the spectator to reconsider their crimes.

8 Yan Brailowsky's excellent article on the paradoxical aspects of forensic rhetoric as seen in Elizabethan and Jacobean dramas involving female killers underscores both the fictionalized and paradoxical nature of such representations, reminding us that "real" women could neither hone their rhetorical skills in court nor appear on stage. With a line-by-line analysis of key passages, he brilliantly demonstrates how the use of enthymeme reveals both unspoken contemporary presuppositions about female killers and possibly provides a commentary on the "'contracted' nature of women's rights legal rights in this period" (63).

9 Taking the study of women who kill across the Atlantic, Alex Gagnon examines the story of "La Corriveau," an $18^{\text {th }}$-century Québec native who murdered her husband with an axe and was hung in chains to rot for her crime. Gagnon first outlines both the facts of the case and the various scholarly approaches surrounding it before examining how $19^{\text {th }}$-century Canadian writers took up the "legend" of La Corriveau, portraying her as either a diabolical sorceress or a Canadian version of Marie Lafarge. In tracing the steps of the fictionalization and legendization of the murderess, he points out complex interactions between historical elements (for example, the discovery in 1850 of the metallic cage in which her corpse had hung), literary trends, and a national desire to preserve the legends and tales of Québec as cultural and literary artifacts. He then explores the ways in which $20^{\text {th }}$ century artists have taken up and transformed the legend of La Corriveau into a martyr of both British and patriarchal oppression. Feminist writers, composers and playwrights have reimagined her "iron cage" as the "glass cage" of patriarchy through on the semantic mobilization of well-known figures and symbols in the various reappropriations of Marie-Josephte Corriveau's story. More restricted in scope, Anne-Sophie Morel's essay on Charlotte Corday, the $18^{\text {th }}$ century French assassin of Jean-Paul Marat, examines how Alphonse de Lamartine's fictionalized representation of beauty and ugliness in this case undercuts perceptions of criminality and blurs distinctions between good and evil. Her analysis of the anaesthetisation of Cordray's demise is particularly convincing.

11 Romain Enriquez focuses on the limits of the epistolary form to give voice to a "mad" murderess in Boucher de Perthe's Emma ou Quelques lettres de femme (1852). He examines the question of agency as he traces the titular murderess's own thoughts on the urges that inhabit her, and draws parallels with Freud's famous patient, Anna O. He also underlines ways in which the overdetermined nature of the various explanations provided in the letters of the story serve to undermine categorization of Emma's actions.

12 Like Enriquez, Mariaconcetta Costantini looks at personalized accounts of women who kill, in this case from a $19^{\text {th }}$ century sensationalist stance in four novels by Wilkie Collins: Armandale (1864), The Haunted Hotel (1879), Jezebel's Daughter (1880) and The Legacy of Cain (1888). Using various autobiographical forms, Collins challenges contemporary scientific and literary norms regarding the fragility of female killers by giving his heroines both mental clarity and individual agency: they know what they are 
doing and why they are doing it. At the same time Collins deepens his exploration of both the criminal mind and of the relation between fiction and reality.

In the final essay of the volume's first part, Martha C. Carpentier reexamines $20^{\text {th }}$ century American writer Susan Glaspell's play Trifles (1916), based on the case of Margaret Hossack, an Iowa mother of 9 who was accused and convicted of killing her abusive husband by taking an axe to his head as he slept. After a brief biographical sketch of Glaspell's life and career, Carpentier outlines various critical approaches to Glaspell's work, ranging from essentialist feminist readings to materialist and intertextual approaches. She finishes her study with an explanation of the Greek figure of nemesis, linking Glaspell's fictional treatment of the Hossack case to a Greek tragedy where the retributive nemesis of justifiable homicide confronts the social nemesis of patriarchy.

With one exception, the second part of Unspeakable Acts turns its focus to contemporary anglophone authors, examining how literature can stimulate reflection about the figure of the murderess (or, more accurately, a variety of women and girls who kill). While it is difficult to summarize Jean-Jacques Lecercle's opening essay on "La petite fille criminelle," it is worth pointing out that Lecercle continues here his work on the concept of archetype and its relations with fiction and literature (164). After a brief evocation of the dialectical and gendered nature of doxa (masculine/feminine, active/ passive, dominating/dominated), the author shows how little girls who kill doubly subvert these binaries: as females and as little girls, they should be passive, dominated and vulnerable. They are not. Lecercle bases his demonstration on murderous little girls on an episode of the X-Files, the main character in The Demon Seed and on the protagonists in Alice Munro's Child's Play. By firmly anchoring the exploration of each character in a specific time and space (chronotope), embracing the singularity of each character, the authors subvert the archetypical figure of the woman who kills.

Munro's Child's Play also serves as the basis for the analysis for Corinne Bigot's study of "play", and for Blandine Pennec's linguistic analysis of the "tensions and blurring effects linked to the use of the coordinator "or"' (199). Bigot focuses on varying types of distance in the text, be they the distance created by a less-that-reliable narrator or the aesthetic distance evident in the description of the act of murder. She evokes the interplay between Munro's text and that of James Hogg (The Private memoirs and Confessions of a Justified Sinner, 1824), focusing on the doubling that occurs between the texts, playing with the destruction of doubles within each. Pennec meticulously traces the ways in which the use of OR calls into question the very notion of agency, revealing the fragility of the semi-confessional assertions found in the text.

Henri Le Prieult also takes a stylistic approach in his examination of Angela Carter's postmodern literary rendition of Lizzie Borden's famous crime in "Fall River Axe Murder" (1985). Through a meticulous analysis of Carter's use of adjective, nominal and modal forms, Le Prieult shows how she calls into question the very act of accusation.

In the case of another short story, A.S. Byatt's "Raw Material" (2003), Sylvie Maurel explores the limits of fiction when it comes to representing violence, referring both to Lecercle's earlier analysis and to Zizek's categorizations of subjective and systemic violence. Maurel examines the violent murder of an ostensibly sweet old lady at the hands of a mute grotesque hag reminiscent of Bertha Mason in the context of a systemic violence of domination within the domestic sphere. Maurel highlights Byatt's 
use of metafictional elements to present this "unspeakable" tale as a kind of writing lesson.

Leaving the realm of contemporary fiction, Ann Sweet-Lecercle comments on the "Dreadful Dames" of Shakespeare, perpetrators of infanticide and, at times, cannibalism. Sweet-Lecercle constructs a "diptych" of the murderous woman with Lady Macbeth on one side and the witches on the other, analyzing the phallic inversion of the nurturing maternal figure feeding on her young in terms of the matta cena.

19 Finally, in one of the strongest essays of the collection, Fiona Mccann explores infanticide and postcolonial feminist identity in the works of South African writer Yvonne Vera. Laying bare the faultiness of maternity, maternal instinct and Mother Africa, McCann shows how societal and individual violence overlap, and how, in a patriarchal, postcolonial context, infanticide can lead to the construction of female agency.

This volume bears reading for the sheer variety of approaches undertaken as well as for the rich, varied theoretical fields explored. Jouve, Guillain and Talairach-Vielmas have put together a collection that speaks volumes.

\section{INDEX}

Mots-clés: meurtre, féminisme, infanticide, littérature, fiction historique, théâtre, stéréotype, violence, études post-coloniales, agence

Keywords: murder, feminism, infanticide, literature, historical fiction, theater, stereotype, violence, postcolonial studies, agency

\section{AUTHORS}

\section{ELIZABETH MULLEN}

Maître de conférences

Université de Bretagne Occidentale (Brest)

elizabeth.mullen@univ-brest.fr 